\title{
ОДНОВРЕМЕННОЕ ОПРЕДЕЛЕНИЕ ХЛОРА, БРОМА И ФТОРА В ПОЛИФТОРАРОМАТИЧЕСКИХ СОЕДИНЕНИЯХ С ПРИМЕНЕНИЕМ ИОНОСЕЛЕКТИВНЫХ ЭЛЕКТРОДОВ
}

Никуличева О.Н. ${ }^{1}$, Чжан Шу ${ }^{2}$, Тихова В.Д. ${ }^{1}$, Фадеева В.П. ${ }^{1,2}$

${ }^{1}$ ФГБУН Новосибирский институт органической химии им. Н.Н. Ворожцова СО РАН, Новосибирск, Россия

${ }^{2}$ Новосибирский национальный исследовательский государственный университет,

Новосибирск, Россия

nast.lastovka@gmail.com

DOI: 10.26902/ASFE-11_123

Определение гетероэлементов, входящих в состав новых синтетических органических соединений, часто характеризующих их свойства, является необходимым при установления точного состава вещества и его чистоты. Для сокращения времени выполнения анализа и количества вещества рационально использовать, если возможно, одновременное определение гетероэлементов из одной навески вещества.

Разработана методика одновременного определения $\mathrm{Cl}, \mathrm{Br}, \mathrm{F}$ в полифторароматических соединениях, основанная на предварительном разложении вещества одним из наиболее эффективных способов - сжиганием в колбе, наполненной кислородом. Для полного разложения полифторароматических соединений применялись добавки, повышающие температуру пламени и улучшающие горение. Условия сжигания и поглощения продуктов сгорания обеспечивают количественное образование в поглотительном растворе галогенов в ионном состоянии, в виде хлорид, бромид, фторид - ионов. Подобраны оптимальные условия определения фтора прямой потенциометрией с фторид-селективным электродом, c последующим определением в этом же растворе хлора и брома осадительным аргентометрическим титрованием с хлорид-селективным электродом. Выполнен анализ веществ с содержанием фтора в интервале массовой доли 7-47 \%, хлора - 7-32 \%, брома - 4071 \%. Относительная погрешность определения галогенов не превышает 1,5%.

Результаты определения массовой доли (\%) фтора, брома, хлора из одной навески исследуемого вещества $(\mathrm{n}=3, \mathrm{P}=0.95)$

\begin{tabular}{|c|c|c|c|c|c|c|}
\hline \multirow{2}{*}{ Вещество } & \multicolumn{2}{|c|}{$\% \mathrm{Cl}$} & \multicolumn{2}{|c|}{$\% \mathrm{Br}$} & \multicolumn{2}{|c|}{$\% \mathrm{~F}$} \\
\hline & Вычислено & Найдено & Вычислено & Найдено & Вычислено & Найдено \\
\hline & 9,04 & $8,95 \pm 0,85$ & 46,76 & $46,66 \pm 0,85$ & 14,52 & $14,50 \pm 0.65$ \\
\hline & 13,22 & $13,43 \pm 0,60$ & 59,59 & $59,28 \pm 0,50$ & 7,08 & $7,02 \pm 0,31$ \\
\hline & 17,38 & $17,24 \pm 0,26$ & 39,12 & $39.28 \pm 0,22$ & 9,29 & $9,23 \pm 0,54$ \\
\hline & 6,82 & $6.73 \pm 0,33$ & 61,48 & $61,42 \pm 0.93$ & 10.95 & $10,83 \pm 0,72$ \\
\hline
\end{tabular}

